\title{
Cultural Mediation: John Eliot's Errand to the Otherness
}

Alice Manuela Martins Guimaraes*

\begin{abstract}
We pretend to revisit and reexamine some of the intercultural encounters between Protestant missionaries and Native peoples in New England in the seventeenth century. We intend to redeem the role that missionaries, particularly, John Eliot, played during the British colonization in the New World, mediating two different cultures, focusing on all the inherent process of intercultural communication. We will argue that during the mission to the "otherness" the English missionary, known as the "Apostle to the Indians", played an outstanding role as a cultural mediator among the natives. During the British colonization in the New World there were great efforts to educate and evangelize the natives. In addition to the education and training of manpower, the missionaries endeavored in another key role: translating Western and indigenous cultures and mediating them. We will try to understand the extent to which a missionary like John Eliot could 'mediate' rather than merely 'translate' in order to improve the communication flow. In this sense, we will explore the income of concepts such as culture, cultural mediation and communication code in the construction of new approaches which allow us to think about the inter-symbolic communication processes. Yet mediation in the New World was not only about the process of translating, interpreting, educating or evangelizing but was, above all, about the process of regenerating the natives and defending them from the land-hunter colonists. We will display that Eliot's errand to the otherness allows us to understand the construction of a native epistemology through the endless task of missionaries who were so committed to proselyting, teaching, educating, protecting the natives' rights and mediating.
\end{abstract}

Keywords: John Eliot; Cultural Mediation; Mission and Otherness

\footnotetext{
Corresponding author: Alice Manuela Martins Guimaraes; Assistant Professor The Humanities Department,Open University, Portugal; e-mail: aligui2@ hotmail.com
} 
Although the origin of the term mediation is in the field of anthropology since the mid- 1900s, when several anthropologists wrote about native people whose role in their society was as a cultural intermediary or cultural broker, cultural mediation among the natives has only been addressed more frequently in the recently works of Paula Montero ( 2006), David J. Hesselgrave (1991), Margaret Connell Szasz (2001) and Serge Gruzinski (2001), among a few others, who focus on both the natives' efforts and on the missionaries', to bridge the gaps between two different cultures. Tribal communities have practiced mediation techniques for centuries. Native Americans adopted their own dispute resolution procedures long before the American settlement. American settlers, by their turn, also developed dispute resolution in the early years. On the other hand, the missionaries, as we will argue in this paper, played an outstanding role as dynamic cultural mediators.

It is however difficult to chart the precise origin of mediation. One reason is, according Hairson, because the history of mediation has often been approached with an "ethnocentric" and "monocultural" viewpoint (1999). It is possible that we may never gain a complete view of the origin of mediation since colonization suppressed or totally extinguished certain cultural practices. On another view, many scholars attempt to address these issues by tracing mediation back to biblical times (Kovach, 2000:25). However, scholarly mediation literature existed as early as the seventeenth century, when the German lawyer and archivist, Johann Wolfgang Textor, (Goethe's grandfather) described essential international mediation standards.

The historiography of seventeenth century missionaries is heated and contentious, with historians agreeing on little except that the missionaries came to America determined to impose their religion, ideology, and culture upon the heathens they encountered. These historians often discount the sincerity of religious motivations and instead emphasize the economic and political benefits Indian conversion could offer colonists. Some of them see the missionaries' aims as commendable, other consider them cynical. The studies that best illustrate this controversy are those of researchers such as Alden Vaughan, Francis Jennings, Dane Morrison, Richard Cogley and James Holstun. 
The institutional histories of Vaughan and Kellaway tended to validate the expressed intentions of the missionaries and their English brethren. Later writers such as Francis Jennings, Neal Salisbury, and James Axtell attempted to place Indian concerns at the center of the story by utilizing an ethnohistorical approach. Axtell has argued that ethnohistory has been plagued by historians' tendency to borrow "a dash of the anthropologist's cultural relativism" (1982:36). In other treatments about the missionaries' task, most notably in the work of Jennings, Eliot and his missionary colleagues are portrayed as agents of English imperialism, intent on using the Gospel as a means of subjugation. Jennings went so far as to describe Eliot as a misleading self-promoter (Jennings, 1971:197-212).

More recently, other scholars such as Richard Cogley and James Holstun have changed completely these taken issues. Cogley tried to redeem vehemently Eliot's contribution to the native's and their culture in New England and Holstun sees Eliot's mission of vital importance to the Indian's civilization. He asserts:

"While it is true that the Praying Towns aimed to
transform the Indians' mode of economic production, it
is also true that the missionaries were not designed to,
and never did, turn a profit (...) the puritan missions
expected nothing from the Indians (...) Neither the
theological nor the political aspect of Eliot's practice is
a mere tool in the service of the other, for the goal of
the Praying Towns was not efficiency but an
unprecedented integration of religious and political
life" (1987: 122)

Yet there is no known research in attempting to connect John Eliot's missionary task, within the intercultural and cross-cultural communication and informed it by a cultural mediation approach. In this paper it's our purpose to argue that the missionaries' goal was a major one. We intend to redeem the role that missionaries, particularly, John Eliot, played during the British colonization in the New World, mediating two different cultures, focusing on all the inherent process of intercultural communication. We will argue that during the mission to the "otherness" the English missionary John Eliot, known as the 
"Apostle to the Indians", played an outstanding role as a cultural mediator among the natives.

Thus we will begin to explore the income of concepts such as cultural mediation and communication code in the construction of new approaches which allow us to think about the inter-symbolic communication processes. As one can easily imagine, successful intercultural communication was by then very difficult to achieve, as it involved a great number of factors, such as language (verbal communication), body gesture (non-verbal communication), the use of time, space and silence, etc., which differ from culture to culture. For all of these reasons, bridging the gap between two people or groups of people who are so different in costumes and cultural issues was a very delicate task. Intercultural communication, indeed, is a complex competence that goes beyond the visible aspects of culture and embraces the so-called invisible aspects, namely those which govern behavior based on the beliefs and values of a given social group. Therefore, it is the translator and interpreter's role to reformulate a message, to communicate ideas and information from one cultural context to another without altering what is expressed in the original text or speech through the language of the writer or speaker. This is the main reason why translators and interpreters actually mediate rather than merely translate, as their task is to facilitate the process of intercultural communication. In this sense, it becomes easy to understand the extent to which a missionary like John Eliot could 'mediate' rather than merely 'translate' in order to improve the communication flow.

The missionaries who desired to meaningfully communicate the gospel to the natives needed to understand people and the particular influences social, cultural, political - that shape them. Further, they must understand themselves and the influences that have shaped them, since their own context influenced how they understood and transmitted the gospel message. Therefore, they must master not only the skill of biblical exegesis but also the skill of human exegesis. This was what Eliot, was able to do soon after he arrived in the New World. We will begin to explore the income of concepts such as cultural mediation and communication code in the construction of new approaches which allow us to think about the inter-symbolic communication processes. In the center of our attention will be the sliding of the cultural concept from the analytic scientific-discourse to the religious and native repertoires in the 
ethnographic context of missions. This is possibly the most important aspect to be considered, concerning the really goals of the missions.

Effective Communication was absolutely necessary for any successful missionary goal, just as it is important in business. According to David J. Hesselgrave, communication is the basic term which describes the basic missionary task persuading people to be faithful and reproducing followers of Christ, "because the missionary's concern is not for the gospel alone but for the whole counsel of God . . . early missionaries understood their commission to make disciples of all nations involved the ultimate in communication" (see Hesselgrave, 1991)

There are several things to consider about communication and missionary organization. Communication is two-way; it is interactive. There is sending and receiving, coding and decoding. As far as models of verbal communication are concerned, they describe how a message is first encoded by the sender by putting it into words and then transmitted to the receiver who has to decode the words to interpret the. Regularly, information is lost or indeed added in this process of codifying and decodifying, as individuals intending to communicate with each other attach different meanings to the code: for different individuals, words have different connotations. The problems of communication are exacerbated when communication takes place across cultures. This is not only due to the basic problem of translation or due to the difficulties for non-native speakers of catching nuances when discussing in a foreign language. Language as a social instrument reflects a culture. Different attitudes to verbal and non-verbal communication are likely to complicate the communication process.

To explore the impact of culture on the mediation process in a meaningful way it is now necessary to define an accurate and useful theoretical framework for characterizing "cultural" differences; to examine the goals of the mediation process; and to explore how this framework might be applied in the mediation process to more effectively accomplish the goals of mediation. Culture is a concept that seems obvious until one tries to define it. Anthropologists have tried different approaches to capturing its essence, and have been unable to reach a consensus. Culture embeds the values, the potential, the particularities and the communicative skills of its subjects, their bodies and the type of interactions between different subjects and with the physical 
environment. A culture is eminently relational. It sets up, mediates, and gauges itself by answering to the otherness. It is, therefore, socially, historically and politically surrounded by the relationship the groups keep by interacting with each other and answering to the otherness.

Kramsh points out, that culture is not about background information, but about acting, interpreting and understanding (1993a). Namely, cultural knowledge is not a case of acquiring information about the foreign culture; it is about being capable of interpreting cultural contexts and actually interacting and performing in those contexts. In the context of mediation, culture is a set of values and beliefs acquired from learning, experiences and social upbringing, which creates implicit social rules or a code of ethics and behavior within a specific group. Culture shapes the way one perceives the world. It is important to see that by having access to/and direct contact with the new culture the missionaries provided the western world knowledge about the other and, at the same time, influenced them.

Mediation, by its turn, is the very root and substance of culture and consciousness. So long as people simply take what is immediately given, then there is no space for the development of culture or consciousness. In the section of the Science of Logic entitled "With What Must Science Begin," Hegel observes: "there is nothing, nothing in heaven, or in nature or in mind or anywhere else which does not equally contain both immediacy and mediation" (Hegel 1969:92). The term 'cultural intermediary' was used in some of the literature, with 'culture broker' and 'cultural broker' as alternatives. Other terms used include 'innovator' and 'mediator'. The genre was given an historical perspective and the field of ethnohistory came into existence. The background to this can be found in the introduction to Margaret Connell Szasz's Between Indian and White Worlds: The Cultural Broker (Szasz, 2001).

The distinction between intercultural and cross-cultural mediation is that the former involves disputants who are of different cultures, whereas the latter involves disputants who are all of the same culture and a mediator who is of a different culture from the disputants. Since we will discuss about the missionaries' contact with the otherness of the New World inhabitants and culture, this article will address both intercultural and cross-cultural mediation. 
And again we realize that there is little consensus to define "mediation" at either the normative or existential level. Most would agree that the process involves intervention of a third person to help parties resolve a dispute, but definitions of the role of that third party and the structure of the process vary considerably. One thing that is consensual is that a mediator must have a wide range of skills and knowledge in order to be able to implement multiple conceptions of the mediation process. For mediation to be effective, it must accomplish the goals which flow from the participants' conception of the process. As William Mazzarella points out, "the neutrality of such action is an ideological or discursive effect, but a powerful one. It has important social consequences for the credibility, legitimacy, and, the seeming naturalness (or im-mediacy) of a given type of mediation" (2004: 356).

Raymond Williams defined the term "mediation" as "an active process of relations between 'different kinds of being and consciousness' which are inevitably mediated" (1977:98). Some scholars in the field of media and communication give mediation a strong theoretical frame, stressing the process of negotiation. The Spanish scholar Martin-Barbero, for example, uses the term "mediation" to denote the articulation between the communication practices and social movements and the articulation of different tempos of development with the plurality of cultural matrices (1993:188).

Moreover he argues (2003) that scholars should attend to mediations (plural) as the cultural processes by which power is negotiated between dominant institutions and popular or resistant movements. MartinBarbero sees communication as a process of mediations and he examines the " 'other' side, namely reception ... the resistances and varied ways people appropriate media content according to manner and use" (Ibidem: 189). This approach is not new to North American communication scholars, but what is new here is a thoroughly Latin American perspective that unveils a refreshing and stimulating panorama of vibrant mediation processes.

Recently, the Brazilian anthropologist Paula Montero (2006) has outlined a theoretical and methodological model, which she called "cultural mediation" and that was central to describe the contexts of interaction between missionaries and indigenous peoples. For Montero, a 
theory of cultural mediation would be the revealing key to understand the role of the missionary activities in contexts of otherness of a world characterized by interculturalism (Montero, 2006:59). The ethnographic description of this type of meeting should consider that the cultural elements present in the interaction and mediation are inserted - and also mediated - by socio-political and broader economic contexts which are a blueprint in the history of contact between indigenous societies and the national society representatives, otherwise we would be risking to limit its analysis to the field of cultural anthropology. In fact mediation is a dynamic principle at the root of all social life.

Keeping on the path of the missionaries' task in the colonial world, the historian Serge Gruzinski (2001: 49) considers the concepts of mediation and mediators outstanding as they both refer to the mechanisms developed by individuals as a means to transpose from a known culture to an unknown one. Cultural mediation places the intercultural competence at the heart of language teaching, particularly when the language is used for specific purposes, namely for translation and interpreting. In this sense it is the process through which a third party acts as a "cultural broker" by assisting both parties to reach a common understanding and to interact more satisfactorily. Cultural Mediation aims to identify the role of culture in social processes triggered in response to alterity, such as that observed in the encounter between natives and Christians in the New World.

Having developed ways of theorizing communication, mediation, culture and cultural mediation, we should move toward exploring its conditions and outcomes on social projects and movements such as the role of missions, particularly that of John Eliot, with the natives that may not be recognized by some scholars in those terms, but as we will argue, it allows us to understand the construction of a native epistemology through the endless task of missionaries who were so committed to proselyting, teaching, educating, protecting the natives' rights and mediating.

Taking as starting point, the concept of cultural mediation, as argued in Paula Montero's, Deus na aldeia: missionários, índios e mediação cultural, (2006) (God in the village: missionaries, Indians and cultural mediation) it will be seen how the missionary task, taken on linguistic and cultural mediation, functioned in the New World, during the 
seventeenth century colonization. Thus in this paper, we will follow the definition advanced by this anthropologist as she sustains that the process of meaning-making is about what the cultural mediation consists of; a communication process whose result is the establishment of meanings shared in social or intercultural areas. For Montero, the locus of cultural mediation is the "social and symbolic" space where relations between Indians and missionaries occur, where the process of construction and meaning is, actually, prepared through their interactions (2006: 59).

Her definition is particularly helpful for me, in looking at what strikes me as a clearly cultural mediation in John Eliot's errand to the otherness as I intend to redeem the importance of his dynamic as a great local mediator. As we know, during the British colonization in the New World there were great efforts to educate and evangelize the natives. In addition to the education and training of manpower, the missionaries endeavored in another key role: translating Western and indigenous cultures and mediating them. Yet mediation in the seventeenth-century New World was not only about the process of translating, interpreting, educating or evangelizing but was, above all, about the process of regenerating the natives and defending them from the land-hunter colonists.

John Eliot was a minister in the adjacent town of Roxbury and the first Englishman to make a serious effort to learn a New England Indian language. He was one of the first missionaries in North America to engage with issues surrounding spoken and unspoken strategies of communication. He began to learn the Algonquian language which did not yet have a written form. Algonquian was a notoriously difficult language. He first began preaching in Algonquian in 1647 (Gray, 2007:1). After several fruitful encounters with the Algonquians, with Eliot speaking to them in their native language, many were Christianized. His was the first sermon ever preached on the mainland in the language of the Massachusetts' natives.

After preaching a while, and explaining the Word of God, Eliot thought that these people ought to have the Bible in their own language. It was a very queer and hard to learn language, but the minister was not discouraged by that. He had the help of an Indian, taken captive in the Pequot War, in the work of translation. It was finished and printed in 1663, and was the very first Bible ever printed in America. This was also 
the first Bible printed for cross-cultural missionary purpose and translated by one of the earliest Protestant missionaries. There are very few copies of this Indian Bible to be found now.

Eliot has been revered for his contributions to Native American linguistics not only because he was the first who began to understand the Massachusetts language on its own terms and not simply in relation to European or Asian languages, but also because he translated numerous other religious texts into the Massachusetts language, a set of works collectively known as the "Indian Library." He brought both literacy and the Bible to the Algonquian people, and reshaped their communities into fellowships of Christ. He believed that they had souls to be saved. It was not easy to win them at first, but by working so hard by and by the natives became devoted to him. He went across the country, once a fortnight, to preach to his Indians. One after another he formed settlements of Praying Indians. He taught them a new way of living, showing them how to raise crops, to build bridges, to make houses and homes, and how to clothe themselves properly. He made them comfortable, and by getting help from others, he made it possible for them to work, and to live as did their civilized brothers.

Singing psalms was also a vital part of Puritan worship in colonial Massachusetts and the missionary incorporated psalmody into his efforts to convert Indians to Christianity. Under the auspices of the Corporation for the Propagation of the Gospel in New England, Eliot headed the Massachusetts Bay Colony missionary efforts, which included translating the metrical psalter into the Massachusetts dialect. Beginning in 1651, Indian converts in so-called Praying Towns across the colony were taught to sing the translated psalms. Music was heavily weighted with spiritual and cultural significance for both colonists and Indians, and sacred music became a mode of cross-cultural mediation between the groups. The newly translated psalms were set to traditional English psalm tunes, exemplifying an uneasy syncretism that discomfited English listeners.

Yet Eliot did not act alone in his linguistic and missionary work. He relied to a great extent on Indian translators, interpreters, and teachers. Over the course of his lifetime, John Sassamon, one of his native scholars, would serve him in each of these capacities. Like Eliot, Sassamon became well known for both his linguistic and missionary 
skills. Within some years, Indian students learning to read would have benefitted from the Indian catechisms and primers that Eliot and his assistants, as Sassamon, would soon translate. Syllable by syllable and word by word, both were mastering new languages, pulling letters apart and pushing them back together again, making familiar meanings out of unfamiliar sounds.

After conversion, Eliot and his colleagues believed that segregation and isolation were necessary for the converts' spiritual growth. The converts must be removed from the negative influence of their pagan relatives and bad white men. Eliot established purely Christian towns of "Praying Indians" so that the new converts could live together under the strict discipline and careful nurture of the missionaries and Indian pastors and teachers. Eliot put his towns under a biblical form of government, a civil model drawn almost exclusively from his reading of the Old Testament political structures and particularly Jethro's advice to Moses in Exodus 18:13-27.

Within the towns, the Indians lived together under a covenant between them and the Lord. Those towns were known as "Indian Praying Towns". Eliot looked upon Natick, the first of such a community, as the model upon which not only other praying Indian towns would be constructed but potentially as a model for England and the rest of the world to emulate. His aspirations for this tiny polity were not only connected to his hopes for Native American evangelism but also to his dedication to a system of government rooted in the Old Testament. Eliot's insistence on running the praying communities by the governmental system outlined in Exodus was a significantly different setup from that under which the English lived. In this sense, Eliot's application of an Old Testament system of government (instead of the New Testament so acclaimed by the puritan English settlers) made it clear that he saw his project in terms that transcended the English concerns. His main goal transcended the colonists' goal.

As we have seen conversion required not only a change of lifestyle and a regeneration of the heart, but a reconfiguring of the mind as well. Eliot's insistence that heart conversion must follow cultural conversion was his ultimate goal. In order to become literate, seventeenth-century Indians had first to make a graduated succession of cultural concessionsadopting English ways and English dress, living in towns, learning to 
speak English, converting to Christianity. But these very concessions made them vulnerable. Neither English nor Indian, assimilated Indians were scorned by both groups, and they were even subject to attack. Because the acquisition of literacy, and especially English-language literacy, was one of the last steps on the road to assimilation, Indians who could read and write placed themselves in a particularly perilous, if at the same time a powerful, position, caught between two worlds but fully accepted by neither.

Actually, both Eliot and his close associate, Daniel Gookin, faced harsh criticism and even physical danger because their association with the Indians. While the apostle and his colleagues certainly attempted to colonize the hearts and minds of their Algonquian audiences, they also validated Native American land claims at the expense of English neighbors. Their association and defense of praying Indians garnered them both suspicion and disdain as King Philip's war solidified radical division in New England. In this context the mission acted as mediator between Native Americans and land-hunter colonists.

In addition to the cultural and literacy improvement Eliot brought the natives, his contribution was also remarkable at defending the natives and protecting them from land-hunters. From the very beginning of colonization the white settlers saw the natives as the "beasts" that must be civilized and subdued. Proponents of colonization could draw upon a number of powerful biblical arguments that seemed to give support to the policies of the colonizers. Biblical narratives and divine imperatives were cited to show that foreign settlements were legitimate and that in most cases they could claim the land property from the natives. The native's nomadic lifestyle might even lead to legitimate settlement and occupation. For the white puritan settlers, the lack of agriculture and absence of the notion of private property were prime evidence of the natives" "bestial status" and would legitimate them to possess the natives' land.

Yet John Eliot tried not only to regenerate but above all to protect that part of the English population with no voice, no law and no discipline, whom the New England puritan settlers saw as displaced people and the "wild beasts". The minister tried to integrate them into the newly rationalized New England landscape. Thanks to Eliot's Praying Towns, the natives were able to learn and to adapt themselves to a sedentary 
lifestyle and to a newly social organization which would protect them from the land-hunters and would give them the legal right to stay in their lands. As Professor James Holstun sates:

The enclosure of New England proceeded that of England. The Indians possessed the lands by natural right... As the enclosure of English commons' ground often began with a single large landholder overstocking the commons, turning it into private property, so white expansion in New England often began with the Indians' allowing whites the use for settlement and cultivation of Indian commons grounds (...) The dispossessed and displaced English tenants and Algonquian tribesmen soon found out that enclosure is irreversible. Just as Winstanley and the Diggers responded to the displacement of rural tenants by encouraging them to enclose and cultivate common grounds such as those at St. George's Hill, so Eliot and his missionary colleagues worked tirelessly to acquire tracts of land for Indian Praying Towns. (107-08)

Furthermore, as Holstun points out, this missionary worked hard to acquire tracts of land for the natives and even increased the property rights that praying Indians held in legal theory. Thanks to his mediation, the British government set apart six thousand acres of land for the "civilized" natives. Richard Cogley, an associate professor of religious studies, stands that Eliot's mission gave the natives a legal right that pagan Indians did not hold, namely, ownership of land that had not been "subdued" through the "possession or improvement" (Cogley,1999:234). Thanks to Eliot's mediation with the British government, the General Court assigned in 1647 "hundreds of acres" to the proselytes (Ibidem: 236).

It will be appropriate here to remark the views of some scholars who don't see the missions and their goals as a purely hegemonic task and who emphasize the religious motivations within the economic and political benefits Indian conversion could offer colonists. As Wolfgang Gabbert states, "in any examination of missions it is important not to reduce the proselytes to an 'undifferentiated mass' evangelized by missionaries who functioned as agents of hegemony" (Gabbert 2001: 293). It is also important to recognize the way in which missionaries could subvert the colonial regime even as they work in concert with it (Karen E. Fields; 1982: 95-108). 
If the mission represented a noble effort to enable the two races to live together, King Philip's war, particularly its impact on Eliot's converts, "signaled the failure of the English and the native peoples to live together peaceably," as historian Jill Lepore has noted in "The Name of War." Richard Cogley, has carefully traced Eliot's missionary activities, placing them in the context of Colonial politics, making it clear that Eliot was not out to destroy Indian culture, but was actually interested in fostering the survival of the native Massachusetts language, which he learned, and of many native customs. Cogley stresses that the mission in Massachusetts Bay was "a means to an end rather than... an end in itself" (1999: 5).

Thus, we believe that characterizing Eliot, his mission and the Praying Towns in stark imperialist terms is misguided. John Eliot was above all an awesome cultural mediator who defended and gave a voice to the muted natives of the New World. As we have displayed all along this paper, the missionary, in addition to his educational and cultural mission, came to play an important role in cultural mediation. The linguistic, social and cultural mediation, led over the centuries by missionaries such as Eliot, was instrumental for the peaceful coexistence of very different communities.

\section{References}

Axtell, James. 1982. "Some Thoughts on the Ethnohistory of Missions," Ethnohistory, Vol. 29, No. 1. 36

Bellin, David Joshua. 2003. "A Little Shall I Say: Translation and Interculturalism in the John Eliot Tracts." Reinterpreting New England Indians and the Colonial Experience. Collin $\mathrm{C}$. Calloway and Neal Salisbury, Eds., Boston: The Colonial Society of Massachusetts

Cogley, Richard. 1999. John Eliot's Mission to the Indians Before King Philip's War. Massachusetts: Harvard University Press.

Fields, Karen E. 1982. "Christian Missionaries as Anticolonial Militants" Theory and Society, V.121 No. 1. pp. 95-108.

Gabbert, Wolfgang. 2001. Ethnology, Vol. 40, No. 4.

Gray, Kathryn Napier. 2007. "Written and Spoken Words and Worlds: John Eliot's Algonquian Translations", in Symbiosis: a Journal of Anglo-American Literary Relations, Volume 7.2 
Hairson, Cherise D. 1999. "African Americans in Mediation Literature: A Neglected Population." Conflict Resolution Quarterly. Volume 16, Issue 4, pp. 357-375,

Hegel, G. W. F. 1969. Hegel's science of logic (A. V. Miller, Trans.). New York: George Allen \& Unwin.

Hesselgrave, David J. 1991. Communicating Christ: cross-culturally: An Introduction to Missionary Communication. Michigan: Grand Rapids.

Holstun, James. 1987. A Rational Millennium, Puritan Utopias of Seventeenth- Century England and America. Oxford: Oxford University Press.

Jennings, Francis. 1971. "Goals and Functions of Puritan Missions to the Indians," Ethnohistory, Vol. 18, No. 3, pp. 197-212

Kellaway, William. 1961. The New England Company 1649-1676: Missionary Society to the American Indians. New York: Barnes and Noble

Kovach, K. 2000. Mediation: Principles and Practice. American Casebook Ser.: West Publishing Company, College \& School Division

Kramsch, C. 1993a. Context and Culture in Language Education. Oxford: Oxford University Press.

Mazzarella, William. 2004. The Annual review of Anthropology, 33:34567 available at http://anthro.annualreviews.org (last access10/09/2013)

Martin-Barbero, J. 1993. Communication, Culture and Hegemony: From the Media to Mediations. London: Sage. 2003. "Cultural change: The perception of the media and the mediation of its images." Television and New Media, 4(1), 85-106.

Montero, Paula (org.). 2006. Deus na aldeia: missionários, índios e mediação cultural. São Paulo: Globo

Ronda, James P. 1977. “We Are Well As We Are': An Indian Critique of Seventeenth-Century Christian Missions." The William and Mary Quarterly. 3rd. Ser., Vol. 34, No. 1.

Salisbury, Neal. 1974. "Red Puritans: The "Praying Indians" of Massachusetts Bay and John Eliot." The William and Mary Quarterly. 3rd. Ser., Vol. 31, No. 1.

Simmons, William S. 1979. "Conversion from Indian to Puritan." The New England Quarterly, Vol. 52, No. 2. 
Szaz's, Margaret Connell. 2001. Between Indian and White Worlds: The Cultural Broker. USA: University of Oklahoma Press.

Vaughan, Alden. 1995. New England Frontier: Puritans and Indians, 1620-1675, 3rd ed., Norman: University of Oklahoma Press.

Williams, R. 1977. "From Reflection to Mediation." In R. Williams (Ed.), Marxism and Literature (pp. 95-100). Oxford, U.K.: Oxford University Press.

Wyss, Hillary. 2000. Writing Indians: Literacy, Christianity and Native Community in Early America. Amherst, MA, University of Massachusetts Press 